\title{
O OFÍCIO DE BARBEIRO EM ICOARACI (PA), DIÁlOGOS COM SEU JORGE ${ }^{1}$
}

\author{
Flávio Leonel Abreu da Silveira ${ }^{2}$ \\ Pedro Paulo de Miranda A. Soares ${ }^{3}$
}

\section{O ofício de barbeiro no distrito de Icoaraci}

O distrito de Icoaraci, situado em frente à baía do Guarajá, dista aproximadamente $18 \mathrm{~km}$ do centro da capital Belém. Atualmente, possui uma população de cerca de 320.000 habitantes. Chega-se ao local através da Rodovia Augusto Montenegro ou da Rodovia Arthur Bernardes. A Barbearia São Jorge, onde realizamos o trabalho de campo está localizada na chamada $5^{\mathrm{a}}$ rua, próxima à Avenida Cristóvão Colombo, uma via obrigatória para os ônibus que se dirigem ao centro de Belém. Sendo assim, o estabelecimento situa-se em uma área relativamente central do distrito.

Ao chegar à $5^{\text {a }}$ rua pela Av. Cristóvão Colombo é preciso dar apenas alguns passos para encontrar a barbearia, locus da pesquisa em questão ${ }^{4}$, de propriedade do senhor Jorge Nazareno da Mata. Trata-se de um prédio pequeno de alvenaria, erguido em frente à casa na qual seu Jorge mora com a família, sendo que logo ao lado, situa-se a morada na qual sua irmã, Dona Maria, vive com sua família. Portanto, o local de trabalho de seu Jorge é um ambiente bastante familiar.

O estabelecimento está localizado no bairro do Cruzeiro, onde durante todo o segundo semestre do ano de 2006 foram realizadas visitas semanais, tanto para conversar com seu Jorge e seus clientes na barbearia, como para visitar parentes e amigos do barbeiro que se dispunham a colaborar com o trabalho.

\footnotetext{
${ }^{1}$ Este artigo resulta da pesquisa etnográfica realizada no ano de 2006 no distrito belemense de Icoaraci e se insere no projeto "Paisagens culturais, memória coletiva e trajetórias sociais. Estudo antropológico das fronteiras culturais no mundo urbano contemporâneo na cidade de Belém - PA", coordenado pelo Dr Flávio Leonel Abreu da Silveira, tendo como bolsista o estudante do curso de Ciências Sociais, Pedro Paulo de Miranda Araújo Soares. O projeto tem financiamento do PARD - Programa Auxílio RecémDoutor -, oferecido pela Universidade Federal do Pará (UFPA).

${ }^{2}$ Professor do Departamento de Antropologia da Universidade Federal do Pará (UFPA).

${ }^{3}$ Estudante do $5^{\circ}$ semestre do curso de Ciências Sociais (UFPA), bolsista do Programa Auxílio Recém Doutor (PARD).
} 
$\mathrm{O}$ artigo em questão busca registrar e compreender as "artes de fazer", para usarmos uma expressão cara a De Certeau (1994), de um barbeiro que atua há mais de cinqüenta anos no distrito de Icoaraci, Belém. Nestes termos, partimos do princípio de que a profissão de barbeiro é um ofício bastante tradicional no espaço urbano belemense, defrontando-se, todavia, com a possível tendência de desaparecer diante da concorrência dos modernos salões de beleza e a emergência dos chamados hair designers.

No entanto, a figura do barbeiro, para além de tal dilema exposto acima, persiste no cenário urbano icoaraciense, constituindo-se num interessante objeto de pesquisa no que tange às "artes de fazer" relacionadas às práticas profissionais associadas às formas de sociabilidade (Simmel, 1983) presentes cidade de Belém. Além disso, é preciso considerar não apenas o barbeiro em sua labuta, mas a sua inserção no bairro, assim como a presença da barbearia e suas relações com o universo dos moradores de um bairro de Icoaraci.

Sendo assim, entendemos que os conhecimentos e técnicas relativos ao ofício de barbeiro estão ligados a diferentes aspectos do mundo urbano em Icoaraci, uma vez que aproximam práticas laboriais a processos de sociabilidade em consonância aos modos de vida dos freqüentadores da barbearia. O presente trabalho, nestes termos, se detém não só a discutir as artes de fazer de um barbeiro, mas as relações deste com seus clientes, considerando tal ofício como parte de um contexto maior, ou seja, o bairro do Cruzeiro em Icoaraci.

Nossas reflexões ao considerarem, principalmente, o material coletado durante o trabalho etnográfico - envolvendo as muitas idas à barbearia -, voltam-se para a discussão acerca das questões relacionadas às técnicas e práticas implicadas num saber específico porque pautado na empiria, posto que foi adquirido por seu Jorge ao longo do exercício de sua atividade de trabalho. Além disso, torna-se necessário destacar a sua forma de se relacionar com seus clientes, também inserida num processo de aprendizagem e aquisição de experiência quanto ao atendimento ao público.

A barbearia é, então, o espaço onde tais fenômenos emergem como elementos importantes nas interações do senhor com o público que busca seus serviços. Isso porque, diante do jogo intersubjetivo vivido na relação proximidade-distância entre o barbeiro e seus clientes é que acontecem as manifestações formais do processo de sociação (Simmel, 1983) no meio urbano belemense. 
Para compreendermos melhor tal universo social fizemos uso de determinados instrumentos metodológicos para a realização da pesquisa, tais como a manutenção de um diário de campo e a utilização do gravador digital, através dos quais eram anotados e gravados os depoimentos de seu Jorge sobre a sua história de vida como barbeiro e as “artes de fazer" relacionadas à sua labuta. Entretanto, muitas vezes a utilização do gravador era impossibilitada pela rapidez e espontaneidade com que os eventos aconteciam na barbearia, sendo necessário fazer uso da caderneta de campo como meio de captar diálogos, gestos do barbeiro e nuances dos momentos de sociabilidade quando emergiam durante a interação entre as pessoas.

A utilização da máquina fotográfica também foi de extrema importância, pois possibilitou aos pesquisadores o registro dos gestos do barbeiro, bem como das suas ferramentas de trabalho e do momento da ação técnica, dado no ato de cortar cabelo e barbear o cliente. Há, portanto, um caráter metodológico no uso de tal recurso que se traduz numa intencionalidade etnográfica, cuja proposição é a de construir uma narrativa imagética, conferindo às imagens recolhidas (dos gestos e instrumentos) uma importância na produção antropológica acerca do urbano, associada à visual. O uso da máquina fotográfica, portanto, permitiu a realização de uma etnografia por imagens, buscando refletir sobre determinados aspectos do saber-fazer do barbeiro naquele contexto urbano.

\section{A barbearia}

A barbearia São Jorge mantém-se como um importante espaço de sociabilidade no contexto da Icoaraci, pelo menos desde a segunda metade do século XX. Ela perdura na paisagem urbana icoaraciense há mais de quarenta anos e figura como um dos lugares de memória da Icoaraci de outrora, posto que se trata de um locus de convergência de pessoas e imagens que evocam uma memória do lugar, ou seja, do mundo urbano belemense.

A barbearia de seu Jorge ocupa este papel porque nela mescla-se o vivido concentrando toda a força do cotidiano, na medida em que sua presença evoca temporalidades distintas que emanam das múltiplas visões, tensões e interpretações do tempo vivido em relação àquele que é pensado, sendo trazidas à tona mediante o esforço de rememorar realizado pelo barbeiro e pelos freqüentadores. As lembranças, nestes termos, consubstanciam-se na dialogicidade inerente ao espaço, mostrando assim uma 
abertura às expressões do tempo e às transformações do espaço urbano - num devir que agrega passado-presente-futuro - entre aqueles que vivem o lugar.

No interior da barbearia é possível encontrar um clima de descontração, pautada sempre no respeito mútuo entre o profissional que ali atua e seus freqüentadores. Tratase de um ambiente predominantemente masculino, mas as mulheres também circulam na espacialidade do lugar, onde conversam com os homens e entre si. Tal aspecto do convívio entre os gêneros na barbearia ficou evidente no dia em que uma amiga de Dona Maria, esposa de seu Jorge, passou algum tempo conversando com a senhora no interior do recinto.

A ambiência da barbearia é bastante agradável ao olhar, trazendo consigo uma simplicidade que se ajusta a um ordenamento na disposição dos poucos móveis e dos objetos de uso do barbeiro presentes no espaço, tudo isso refletido na limpeza evidente do estabelecimento.

Nas paredes do local encontra-se, pintada sobre azulejos, uma imagem de São Jorge sobre seu cavalo lutando contra o dragão: imagem potente que evoca o nome da barbearia e faz referência ao próprio nome de seu proprietário, simbolizando a batalha contra o mal que, neste caso, parece desdobrar-se na luta cotidiana pela sobrevivência que o barbeiro ali trava.

Logo acima do espelho, localiza-se um quadro com a imagem de Santa Luzia, a santa dos olhos, representando novamente a fé e a luta de seu Jorge contra uma doença que lhe acometeu os olhos. O pôster com o time campeão do ano, o Internacional de Porto Alegre, obtido a partir de um encarte do jornal está, com certeza, colado na parede, assim como o cartaz que anuncia o Círio de Nossa Senhora das Graças.

O aparelho de som que seu Jorge ganhou de sua filha em seu aniversário de setenta anos está situado numa posição privilegiada no recinto, ficando, geralmente, sintonizado em uma rádio comunitária de Outeiro ${ }^{5}$. Por fim, o jornal do dia está invariavelmente disponível sobre uma das cadeiras da barbearia a quem se interessar em lê-lo ou, simplesmente, folheá-lo. Para seu Jorge o jornal possui um grande valor na sua concepção do que deve ser uma barbearia:

“É, sempre, ainda continua nisso: tem um jornalzinho, né... É, tem um jornalzinho aqui, cara vendeu o jornal... E barbearia também tem uma coisa que eu modifiquei, né, que eu disse: 'Não, isso quando eu tiver minha barbearia não vou fazer!' Tinha um primo que tinha uma barbearia que ele... lá jogavo dama, né. Sabe o que é dama? Jogo de dama. Aí, eu sei que teve uma briga lá

${ }^{5}$ Outro distrito da cidade de Belém situado próximo à Icoaraci. 
e já perto tinha um bar, tomavam cerveja, acertaram com a garrafa o espelho dele [?] 'No dia que eu for dono num vou botar isso, ponho um jornal!'... Esse negócio de jogo dá bebida, de apostar... eu num consinto jogo aqui na barbearia, não... Bate-papo; quer um rádio pra ouvir."

O jornal e o rádio, para seu Jorge, fazem parte do ambiente de sociabilidade criado para fazer com que o cliente se sinta bem na sua barbearia. Ambos, portanto, substituem o jogo e a bebida, afastando a confusão e a violência do espaço familiar como é a barbearia São Jorge.

\section{A trajetória de seu Jorge como barbeiro}

Diante da pergunta acerca de quando o senhor havia iniciado o seu ofício de barbeiro, respondeu com base em suas recordações de infância, o seguinte:

\footnotetext{
"Rapaz, desde o início mesmo, o primeiro cabelo que eu cortei foi da mãe do Gilmar [dona Maria, sua irmã]. Esse eu me lembro, foi o primeiro. É, eu tinha oito anos de idade (...) Primeiro cabelo que eu me lembro que cortei foi o da Maria, que ah... Meu pai levava a gente pra cortar cabelo: eu ficava olhando assim, né. Barbeiro cortar o meu... Aí, quando foi um dia, que minha mãe saiu pra comprar comida à tarde, nesse tempo era diferente, não tinha asfalto, não tinha nada, só esse chão mesmo. Aí, o que era mato, caminho. Aí, ficamos nós três na casa. Aí, eu:

- Bora brincar de barbeiro!

- Bora!

Aí, pegamo a tesoura dela cortar pano (risos). Aí, larguei no cabelo da menina. Tinha o cabelo por aqui assim (risos). Porra! Cortei, cortei, cortei... Isso, aí, olha, me rendeu foi uma surra! Por que quando ela chegou o ajudante [não se] segurou: "Quem fez isso na menina?" E ele pontou logo. Primeiro que apanhou olha, eh... [...] tinha um quintal, como eu acabei de lhe dizer, era sempre cheio de fruta, tinha um pé de bananeira. Aí, coloquei lá o cabelo, aí, fui apontar onde tava, de lá eu vim apanhando. Depois que acabou de apanhar, surra no outro também. Aí, eu continuei ainda como barbeiro, né! E o outro desistiu, o ajudante, né..."
}

A narrativa de seu Jorge é importante para compreendermos aquilo que seria para sua irmã, cujo cabelo foi cortado por ele, uma espécie de destino: "É, ele tinha mesmo que ser barbeiro!", diria dona Maria numa conversa informal acerca do episódio. Portanto, um momento singelo, vivido como mera brincadeira de crianças, traz consigo o sério - revelado na simbólica do jogo - enquanto dimensão projetiva do ser dada na intersubjetividade que emerge da experiência lúdica.

Ao lembrar de sua travessura de criança, o senhor estabeleceu uma relação entre o brincar e o ofício de barbeiro, vinculando a criança feliz que foi outrora à ludicidade que, de alguma maneira, o lançou no mundo da labuta - sendo a última um duplo da primeira -, pois o jogo prepararia simbolicamente a criança para agir com seriedade 
naquele que é o ordinário do universo adulto, uma vez que não existe jogo sem regras, ou seja, sem o sério ${ }^{6}$.

O infante, ao escapar da ilusão (i-ludere) - a vertigem do duplo - vivida na experiência do jogo, libera a imaginação e abre espaço para o devaneio da "vontade de trabalho" sobre a matéria (Bachelard, 1991). Ao cortar o cabelo de sua irmã, instaura-se um devir, uma projeção para o futuro que associa o lúdico à labuta no menino, porque, mais tarde, a criança que sonhou com um ofício torna-se o adulto que age no mundo e constrói sua trajetória de vida como barbeiro.

Neste sentido, Focillon (2001) em seu "Elogio da mão", ao refletir acerca da arte e o ofício do artista plástico, nos oferece pistas para pensarmos a relação entre os devaneios da criança e as artes de fazer do barbeiro. De acordo com o autor:

\footnotetext{
"A arte faz-se com as mãos. Elas são o instrumento da criação, mas, antes de mais, o órgão do conhecimento. Para qualquer homem, já o demonstrei; para o artista mais ainda, e segundo vias particulares. Porque ele reinicia todas as experiências primitivas (...) Enquanto nós recebemos o contacto passivamente, ele procura-o, testa-o. Contentamo-nos com um saber milenar, um conhecimento automático e talvez já embotado, escondido em nós. Ele leva-o para o ar livre, renova-o - parte da origem. Não acontece o mesmo com a criança? Mais ou menos. Mas o homem feito interrompe estas experiências e, porque é "feito", cessa de se fazer. O artista prolonga o privilégio da infância bem para lá dos limites dessa idade. Ele toca, apalpa, calcula o peso, mede o espaço, modela a fluidez do ar para aí prefigurar a forma, acaricia a superfície de todas as coisas, e é com a linguagem do tacto que compõe a linguagem da vista...” (Focillon, 2001:115).
}

Por outro lado, Halbwachs (1990) nos mostra que a lembrança precisa de um forte quadro de referência para que emerja como experiência sensível resultante do exercício da memória. Maior é a intensidade da recordação dos acontecimentos quando a pessoa que rememora encontrava-se junto à outra ou, mesmo, a um grupo representativo em sua vida. Seu Jorge recorda-se do ocorrido porque, ao mesmo tempo em que o fato aponta para a descoberta do prazer em cortar cabelos, remete à sua infância junto a sua família.

O fluxo da memória do senhor leva-o a recordar de momentos de sua vida relacionados ao final da adolescência. Época na qual ele e o irmão ajudavam o pai no trabalho como oleiro. Nesse processo, seu Jorge reencontra as imagens da infância relacionadas aos cortes de cabelo junto aos primos:

“Aí, comecei, né! Eu fui com meus primo pra Belém, me lembro bem que eu tinha, fazer uma
cirurgia aqui no ombro. Olha, tá aqui até a marca! Cirurgia aqui no ombro... [mostra a marca da
cirurgia] Cirurgia aqui no ombro. Aí, eu fui pra casa da minha tia. Aí, meus primos eles
cortavam cabelo na sala, três. Era Guilherme, Raimundinho e Paulo. Era o... Aí, eles gostavam

${ }^{6}$ Acerca da simbólica do jogo ver Johan Huizinga (1990). 
de cortar cabelo, mas de tirar barba, não! Aí, eles me ensinarum a, a tirar barba. Quando chegava aqueles velho eu que tirava a barba dos velho, sabe. Chegava aqueles velhinho, aí, eu que ia tirando a barba. Aí, cabelo já era... assim... Aí, foi o tempo que eles se alistarum foram pro, um foi pra Aeronáutica e dois foram pra Marinha. E eu como era magrinho assim, num passei, olha. Aí, fiquei”.

Sendo uma profissão tradicional, o barbeiro trabalha com aprendizes e, não raro, um filho segue a vocação do pai, como ficou evidente em vários relatos de seu Jorge quando este se referia aos demais barbeiros presentes em Icoaraci. No caso de seu Jorge, sua família já possuiu seis barbeiros. Foram três primos na família do pai - Tralhoto, Fidélis e Bené - e três primos pertencentes à linhagem materna - Guilherme, Raimundinho e Paulo -, sendo este último trio o responsável pela iniciação de seu Jorge no ofício de barbeiro. No entanto, quando se fala na inspiração, ou mesmo em uma tímida descoberta da vocação, seu Jorge reporta-se novamente à sua infância, mais especificamente à figura de um antigo barbeiro de Icoaraci, cuja pessoa havia sido mencionada noutro momento.

\footnotetext{
"O senhor conheceu um barbeiro chamado Cachaça?" (Pedro)

"Conheci. Todos os dois: pai e filho. Esse barbeiro".

"Tinham dois?" (Pedro)

"Era, era. O pai era o Cachaça, velho, depois ficou o Cachaça, filho. Já morreram, todos dois. Já morreram! O Cachaça, o meu pai me levava pra cortar cabelo com ele. Ele tinha uma barbearia aqui onde tem essa farmácia, né. Essa farmácia Extra Farma, mas num ia, mas não existia, era o Ozémaria, aí, atrás tinha a barbearia. Aqui era diferente o prédio, aí, é um prédio novo agora. Aí, onde é essa farmácia era o Ozémaria. Era um português, aí, com "O” grande, "O”zemaria. Era um português. Eu era menino e meu pai me levava pra cortar cabelo cum o Cachaça e o China. Era os dois barbeiros que trabalhavam lá. Me lembro... Eles também que... é... teve aquela inspiração, que via cortando, ficava olhando, né... Brincar de barbeiro... te contei daquele vez, né? Brincar de barbeiro... Cachaça!... Morreram todos dois já. O pai, o pai morreu há muito tempo, depois morreu o filho".
}

Aos olhos do menino, a experiência lúdica e prazerosa de cortar cabelos ressoava na figura quase mística do barbeiro do bairro, convergindo, mais especificamente, com a imagem inspiradora do velho Cachaça: imagem-arquétipo evocada na simbólica do jogo, quando seu primeiro corte de cabelo revelou-se um devaneio cuja vontade é a de estetizar e dar forma à matéria moldável que era o cabelo da irmã.

A imagem de Cachaça está intimamente ligada àquela de sua barbearia e, ao lembrar do senhor e tecer uma narrativa acerca de seu ofício, seu Jorge não deixa de situar o estabelecimento na paisagem urbana da Icoaraci de outrora. As lembranças do velho barbeiro, enquanto personagem que realiza uma prática tradicional, tendem a se 
confundir com o processo de transformação ocorrido nos espaços do bairro e a conseqüente modernização dos mesmos.

Tal dinâmica está atrelada às vivências das pessoas que trabalhavam, moravam ou circulavam nesses espaços durante a sua infância. Sendo assim, seu Jorge recorda de uma paisagem - enquanto um fenômeno do ser que engloba o próprio ser em sua ação no mundo - que não existe mais, uma vez que nem o lugar persiste como era e nem seus antigos habitantes vivem mais. Trata-se de uma paisagem fantástica relacionada às imagens mentais, porque se refere à função fantástica da memória considerando-a uma dimensão sensível do imaginário.

Além disso, a narrativa do senhor revela que após a realização da cirurgia e a sua experiência junto aos primos em outra porção do mundo urbano belemense, seu Jorge retorna a Icoaraci trazendo consigo os primeiros passos na sua trajetória de barbeiro vividos como um aspirante à profissão. No entanto, seu Jorge continuou a trabalhar na olaria com seu pai, conciliando o ofício de oleiro com a de barbeiro. Porém, com o passar do tempo esta dupla jornada de trabalho deixou de acontecer, pois segundo ele:

\begin{abstract}
"Eu cheguei fazer aquelas boca de fogão pra cozinhar carvão, ainda tem umas bocas de barro, eu fazia aquilo... Antes de barbeiro, né. Eu já cortava cabelo e já fazia aquilo. Trabalhava na bar... na olaria. Trabalhava de segunda a sexta; sábado e domingo eu ia pra barbearia. Aí, ganhava mais na barbearia que na olaria. Tinha esse negócio de cortar cabelo só sábado e domingo. Sexta, sábado e domingo".
\end{abstract}

Aqui é preciso refletir sobre a relação complexa existente entre a mão e o gesto, posto que tanto no caso do oleiro ${ }^{7}$ quanto no do barbeiro, o gesto técnico encerra um "valor táctil" (Focillon, 2001) vinculado às "sensações da mão" de enorme importância simbólica, na medida em que engendra expressões formais e representações próprias de um determinado contexto sócio-cultural em que a mão revela "a sua linguagem cuja expressão se liga à visão" (Leroi-Gourhan, 1990:209).

A mão, pela via complexa do gesto, engendra estéticas que evocam imagens ligadas a uma simbólica singular relacionada ao lugar de pertença dos sujeitos. Nestes termos, a mão cria imagens e símbolos compartilhados pelos grupos no espaço vivido que expressam, através das formas, certas visões de mundo.

Seu Jorge, durante determinado período de sua vida, utilizará suas mãos para exercer ofícios nos quais elas são de enorme relevância, uma vez que moldam e

\footnotetext{
${ }^{7}$ Para uma reflexão acerca do ofício do oleiro e sua relação com a mitologia entre os grupos indígenas, ver Lévi-Strauss (1986).
} 
delineiam formas a partir de determinadas técnicas corporais (Mauss, 1974) relacionadas aos ofícios de barbeiro e oleiro, respectivamente.

Segundo o narrador, muitas vezes cortava os cabelos dos demais empregados da olaria, sendo que esses lhe pagavam quando recebiam seus salários. Portanto, aquilo que começou como uma brincadeira de criança, paulatinamente se transformava numa atividade profissional que lhe dava lucro e, certamente, prazer, parecendo ser uma atividade a qual prezava mais que a de oleiro.

Seu Jorge, assim como todo barbeiro, começou como aprendiz na barbearia de seu Cícero, indo até lá todos os sábados enquanto ainda se mantinha na olaria durante a semana:

\begin{abstract}
"Aí, tinha um barbeiro por nome seu Cícero aqui em Icoaraci. Nessas altura, eu trabalhava na olaria com meu pai, já, sabe! Trabalhava fazendo ... ajudando a fazer telha e fazia também alguma coisa pra ganhar dinheiro na olaria. Quando era dia de sábado, eu ia. Morreu esse seu Cícero e ficou eu e o filho dele, o Zeca, seu Zeca. Aí: 'Vem pra cá!' Aí, então, adianta, quando era semana muito movimentada, de meio de mês eu ia. Eu ia sábado e domingo, era... sábado e domingo trabalhar na barbearia. Aí, eu notava que eu ganhava mais do que na olaria, olha... Trabalhei um... Esse meu primo Guilherme, por sinal, ele é falecido. Ele me deu umas ferramentas. Ele foi pra Marinha, né. Melhorou e me deu umas máquina... pente, navalha eu comprei. Naquele tempo era diferente as ferramentas, as máquinas eram manuais... Aí, ele... Eu conse... eu... eu consegui com o Zeca, que era o barbeiro que o pai tinha morrido. Aí, fiquei com ele. E nós ficamo, eu trabalhei bem uns oito ou dez anos parece. Trabalhamos numa barbearia aqui na Cristóvão Colombo, aliás, nas duas, mas depois passamos mais adiante, passando a $3^{\mathrm{a}}$ rua com a... outra casa alugada, lá. Aí, de lá que eu vim pra cá, que lá venderam a casa, o senhor do lado, um português comprou".
\end{abstract}

Seu Jorge deixa claro em sua narrativa a importância de adquirir as ferramentas para a execução das artes de seu ofício. Há uma dimensão operatória vinculada a uma função estética (Leroi-Gourhan, 105:1987), que estão intimamente relacionadas à adequação da forma de suas ferramentas à rítmica das mãos suscitadas pela ação sobre a matéria, no caso os cabelos e a barba. Tais dimensões da ação sobre a matéria visam a produção de formas novas e estetizadas, a partir do processo de liberação da memória pela via do gesto técnico associado à dimensão criativa, dada na elaboração de imagens do Outro.
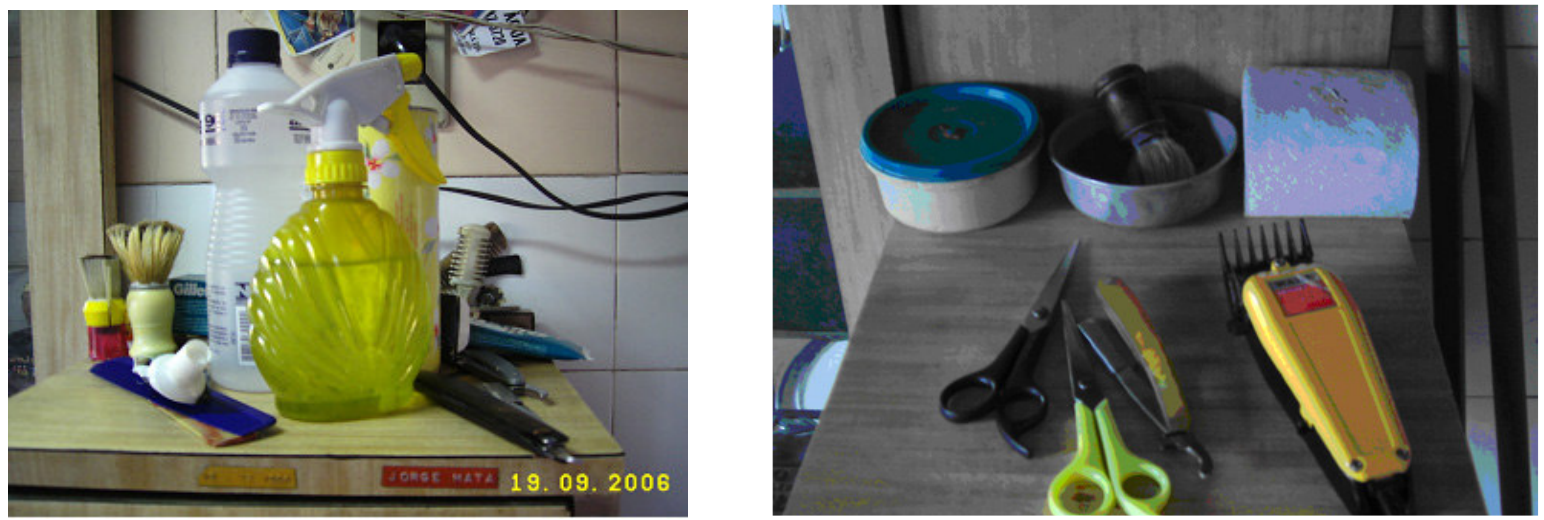


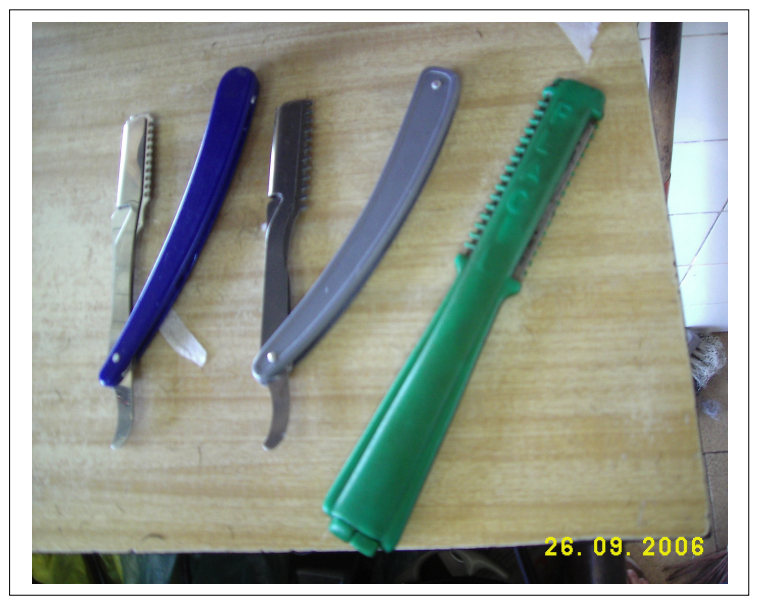

Passados aproximadamente nove anos desde o começo de suas atividades como barbeiro, apresentou-se a oportunidade de seu Jorge montar a própria barbearia. O estabelecimento transformou-se ao longo do tempo, pois no início era de madeira, situando-se no mesmo lugar onde hoje está erguida a construção de alvenaria. Seu Jorge nos conta a história sobre como conseguiu começar a trabalhar em sua própria barbearia:

\footnotetext{
“Aí, o cumpadre da minha mãe que era português, me ajudou a fazer aqui a barbearia. Aí... antes de fazer aqui, eu cortava na sala de casa. A sala era uma casa, não dessa, aí, mas duma outra de madeira. A minha mãe eu me lembro que criava porco: vendeu um porco e comprou uma penteadeira com três espelhos. Eu botei na sala, era três espelhos, n'era? Um aqui, outro aqui e outro aqui, só que era menores. Aí, eu cortava cabelo da, dos garotos todos ali. Aí, o... eu sei que foi movimentando, movimentando. Aí, vinha gente cortar na sala de casa, mas não era apropriado a sala de casa, né! Aí, esse cumpadre dela:

'Eu vou fazer uma barbearia pra ti!'

Aí, eu disse lá pro rapaz da outra barbearia, que ele continuou lá trabalhando. Eu disse:

- Olha ele vai fazer uma barbearia pra mim!

'- Ah, tá. É bom ali?'

- É bom, não tem quem faça, não é na esquina, mas fica próximo à esquina.

Aí, o... quando é um dia, ele chegou. Uma segunda-feira ele trouxe dois esteios:

'- Olha, tá aqui os dois esteios pra fazer a barbearia!' Que a primeira, minha barbearia foi de madeira.

Aí, trouxe dois esteio. Eu disse lá pra ele:

- Olha Zeca, o cara já trouxe os dois esteio...

Que às vezes eu trabalhava lá, que tava pegando, ele me chamava e eu ia pra lá com ele. Aí, eu, dois esteio:

- Iiih rapaz, daqui pro ano dois mil ele...(risos) Ainda era nos anos 60, por aí, assim...

'- Aí, ele apronta!' (Seu Gildo).

- É, aí ele apronta!

Rapaz, passaram-se três meses. Aí, continuei, né. Num tinha pedido, né? Aí, depois, ele chegou com mais dois esteio, que eram os dois dali, assim (risos). Aí, eu:

- Olha, o cara...

- Iiih rapaz, agora que ele trouxe?

'- É...'
} 
Com oito dias ele trouxe to... eu também não reclavamava, tá entendido? Com oito dia ele trouxe material, carpinteiro, tudo, aí, fizeram. Não chegou nem 15 dias... fizeram tudinho: era cimento e tudo, mas num era forrado... barbearia de madeira. Aí, eu vim pra cá cortar cabelo. Primeiro cabelo que eu cortei foi dum rapaz que mora ali. Ele deve tá com quarenta, quarenta e quatro anos, sabe? Uns quarenta e quatro pra quarenta e cinco anos. E ele... até agora, às vezes ele corta cabelo comigo, sabe! Aquele dono daquele bar ali. Aí, o... aí, foi progridindo, né.

Depois de 15 anos trabalhando com, depois de 15 anos trabalhando com madeira, aí que eu consegui fazer de alvenaria, sabe. Aqui tá até hoje de alvenaria, eu já tenho aqui quarenta, vai fazer quarenta e dois anos em dezembro, dia 15 de dezembro, que por sinal é aniversário do meu pai. Se ele fosse vivo ia fazer uns cento e dois ano, parece. É, cento e dois ano, que ele nasceu em 1904, né. Se ele fosse vivo, morreu com setenta e, faz muito tempo, ele morreu com setenta e três anos. E de lá eu to aqui nessa, né. Já muita gente que sentou nessa cadeira já morreu, muuuito mermo! (risos)"

A partir dessa narrativa é possível identificar alguns aspectos da Icoaraci da segunda metade do século XX, como por exemplo, a prática relacionada ao "apadrinhamento", ou seja, as figuras do padrinho e do afilhado revelam formas de interação de forte caráter simbólico-afetivo entre as "comunidades amazônicas"8.

Como nos mostra Galvão (1955), o costume de apadrinhar alguém era uma prática tradicional no contexto amazônico e estava ligado às dinâmicas sociais que consolidavam alianças de solidariedade envolvendo famílias e pessoas, estabelecendose um parentesco por compadrio relacionado a um modo de vida associado às irmandades religiosas, festas de santo e arraiais que sedimentavam solidariedades vinculadas às expressões caboclas de sociabilidade.

Quando duas pessoas se "apadrinhavam” era estabelecido, por livre e espontânea vontade de auxiliar uma à outra ${ }^{9}$, o compromisso de trocas de favores e benesses para toda a vida entre ambas. A barbearia de seu Jorge foi construída por um "compadre" de sua mãe, provavelmente dentro desse espírito de auxílio e reciprocidade em relação ao outro ou talvez retribuindo um auxílio que recebera outrora.

A história da construção da barbearia representa um momento significativo na história de vida de seu Jorge, enquanto barbeiro que construiu sua vida profissional no distrito de Icoaraci. No entanto, a história da barbearia - pontual, microscópica também se cruza com a de diversos outros atores anônimos que por ela passaram ao longo de sua existência, sendo um elemento importante na persistência da memória coletiva do bairro e das próprias memórias de seu Jorge.

\footnotetext{
${ }^{8}$ Utilizamos o termo a partir de Charles Wagley (1988).

${ }^{9}$ A reflexões de Mauss (1974) relacionadas à dádiva enquanto expressão de reciprocidade entre grupos e pessoas - o dar, receber e retribuir - é uma realidade vivida pela experiência cabocla no mundo amazônico que mescla espontaneidade e obrigação nas relações sociais.
} 
Portanto, a memória do bairro passa parcialmente pela experiência pessoal do barbeiro naquele distrito. Sendo assim, a barbearia de seu Jorge ocupa um lugar importante no mundo urbano local, pois nela convergem algumas imagens e lembranças de Icoaraci. A barbearia figura no cenário como um locus da memória, representando um espaço no qual o ato de rememorar, realizado pelos antigos moradores que a freqüentam, revela os anseios e desígnios da coletividade que se faz presente nele.

Cada história narrada ou objeto manuseado, por certo, traz à tona a lembrança de algum personagem, bem como de práticas relacionadas a uma maneira de viver e labutar confrontadas com a crescente modernização dos costumes e das paisagens locais. Não surpreende que seu Jorge afirme: “Já, muita gente que sentou nessa cadeira já morreu, muuuito mermo!"

Se os objetos estão inseridos numa simbólica que fala da vida das coisas, de um espírito que os animam, estando representado na própria força da coletividade que os coloca num circuito de significações - opera-se com eles a partir de gestos que fazem com que sejam manuseados e utilizados, a partir de certas técnicas e de determinados contextos -, os móveis e ferramentas da barbearia estão inseridos num sistema de significação ligado às artes de fazer do barbeiro ao longo dos últimos cinqüenta anos, figurando dentro dos quadros da memória icoaraciense. Nestes termos, teríamos alguns elementos presentes na barbearia que possuem uma memória vinculada à trajetória de vida de seu Jorge.

\section{Instrumentos e ferramentas de trabalho}

\subsection{O Espelho}

“Esse espelho, aí, eu comprei de um freguês meu que era... ele era polícia reformada, polícia civil
reformada. Ele me contou a história desse espelho, aí. Esse espelho, ele, ele ia casar sabe! Ele era
agente policial. Ele ia casar com uma moça duma família mais ou meno do que a dele, né! De um
nível mais elevado, e eles num querium que ela casasse com investigador de polícia, né. Aí, tal, e,
como assim, ele não tinha nada! Mas mesmo assim ela quis casar com ele e casarum. Todos dois já
são falecido. Então, no início do casamento, ele num, ele alugou uma casa. Ele tinha uma mesa,
dois banco, uma cama, uma coisa toda de... não tinha quase nada. Quando passou um moleque
oferecendo um bilhete da loteria, né. Aí: 'Olha compre mestre, compre um bilhete da loteria, aí, o
senhor quer?' Aí, ele comprou. Aí, deu o primeiro prêmio, ele ganhou na época, era, o dinheiro se
falava-se em conto. Dois conto de réis. Dois conto de réis, eu num sei... deveria ser hoje, o quê?
Não posso nem calcular isso! Dois conto de réis. E desses dois contos de réis, aí, sim, ele comprou
casa, comprou móveis, aonde veio esse espelho. E não era assim. Isso, aí, só tá o espelho, era um,
ainda cheguei a ver o móvel. Embaixo tinha uma, umas gavetas, assim. Era onde as mulheres ia se
preparar pra meter espartilho, um negócio que faziam até de barbatana de baleia (risos) que era pra
ficarem bem, né. Olhava assim: poxa! Tirava aquilo e a barriga caía (risos), ou deveria ser, né?
Andavam toda apertadinha, ium pra festa, nem comiam muito (risos). Ficavam elegantes. Então 
tem essas coisas, né, rapaz... E, taí, a história do espelho, né. Já, tá há muitos anos na minha mão. E eu comprei ele, já, a barbearia ainda era de madeira”.

O espelho, sendo visto como um objeto relacionado diretamente à apreciação estética de si e do outro, consta como uma parte fundamental do mobiliário presente na barbearia. A história relacionada à chegada do espelho ao estabelecimento confunde-se com a trajetória de vida de pessoas conhecidas de seu Jorge, ao mesmo tempo em que o faz rememorar acerca de padrões estéticos de antigamente, quando o espartilho era um elemento fundamental na indumentária e na beleza das mulheres belemenses.

\subsection{O Móvel}

“Aí, um outro senhor que já faleceu que fez, o seu Joaquim, aí da São Roque. Ele que ordenou isso pra mim: 'Bora fazer um movi bacana assim, compra um espelho!' Aí, fez esse móvel, desenhou e fez esse móvel. Ficar bom, fica!”

Os móveis prestam-se muito bem aos devaneios como indica Bachelard (1988) em suas reflexões sobre o espaço. Em sua narrativa, a imagem do móvel suscitou a do espelho, mas antes ele precisou ser projetado, sonhado como tal, para compor o espaço da barbearia. Daí, os devaneios do repouso (Bachelard, 1990) a estimularem e promover os devaneios da vontade (Bachelard, 1991), de maneira a construí-lo a fim de fazê-lo compor a barbearia de seu Jorge.

\subsection{A Cadeira}

"E essa cadeira aqui, eu comprei a prazo na Mesbla. Na época do cruzeiro eu cortava cabelo a dois cruzeiros. E essa cadeira custou seiscentos. Eu paguei de dez vezes, dei uma entrada mais nove. Sessenta, né... Então eu fazia assim: todo dia, quando tirava dois, por mais que nem cortasse cabelo, tinha que guardar dois cruzeiros. Aí, dava sessenta cruzeiros. Chegava no fim do mês, pra pagar a cadeira. Humm... custou seiscentos. E vou levando a vida assim, até quando Deus quiser, né! Também... muita gente já passou por aqui, criança, adulto, velho...".

A memória relacionada à barbearia não é apenas a memória de seu Jorge, mas também à de todos aqueles que por ali passaram e guardam um pouco das lembranças ligadas a história de vida do senhor no local. Entre os clientes que seu Jorge cortou o cabelo para pagar a sua cadeira em dez vezes, figura seu Joaquim. Trata-se do homem que construiu o móvel onde está fixado o espelho, vendido a seu Jorge por seu amigo investigador de polícia. 
Muitos dos que sentaram na cadeira ou apenas adentraram a barbearia para um bate-papo amigável já faleceram, mas seu Jorge permanece, apesar de certa precariedade da vida - no sentido da passagem pelo mundo mais ou menos efêmera porque ligada a finitude do ser. Porém, todos deixaram sua marca no local, pois sua presença se faz sentir novamente através do "trabalho da memória" (Bosi, 1994) do barbeiro, homem cuja trajetória correu em paralelo à de seus clientes e vizinhos. Isso o torna um conhecedor do cotidiano do bairro ao longo do tempo e, por isso, um guardião da memória (Benjamin, 1980)

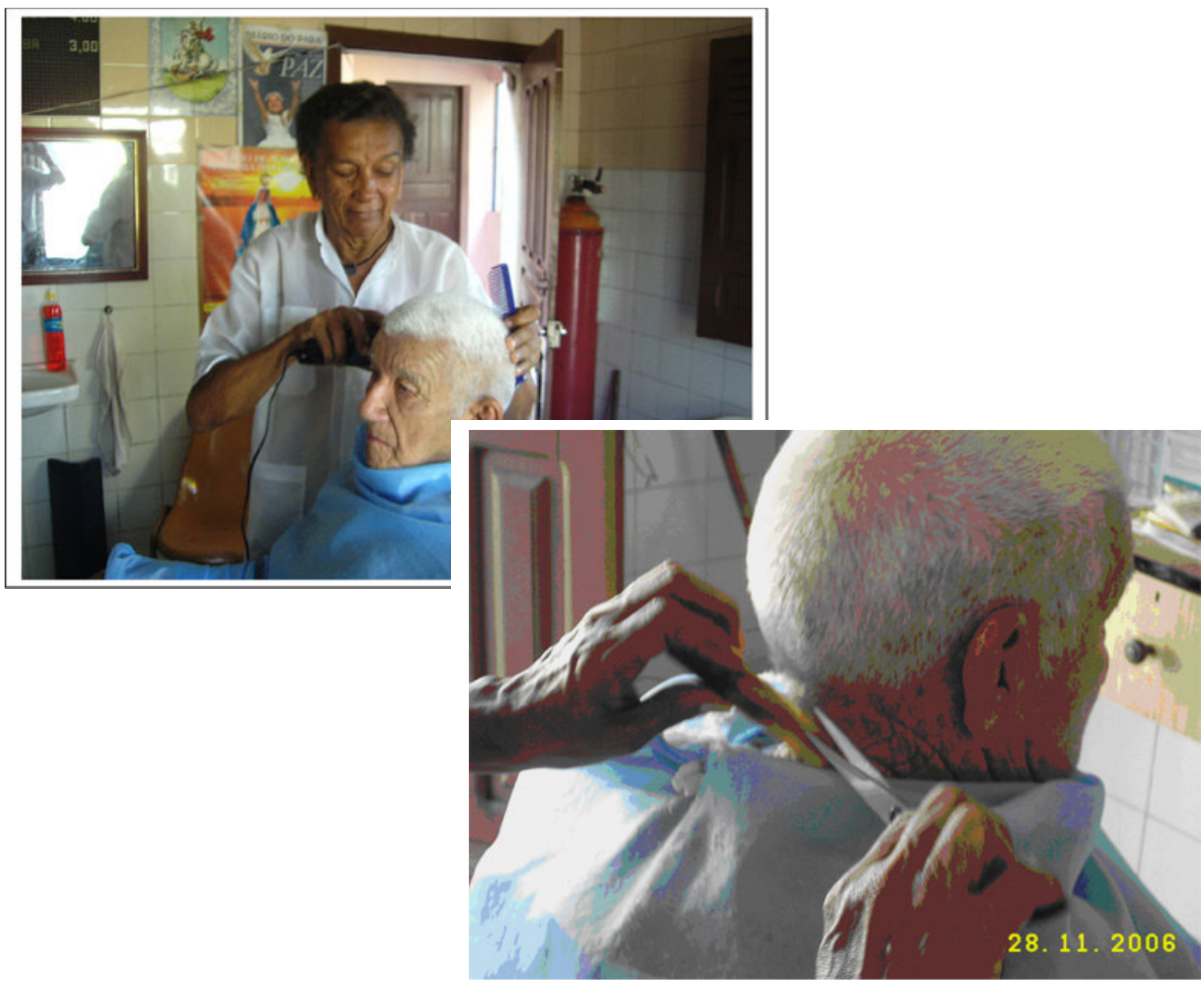




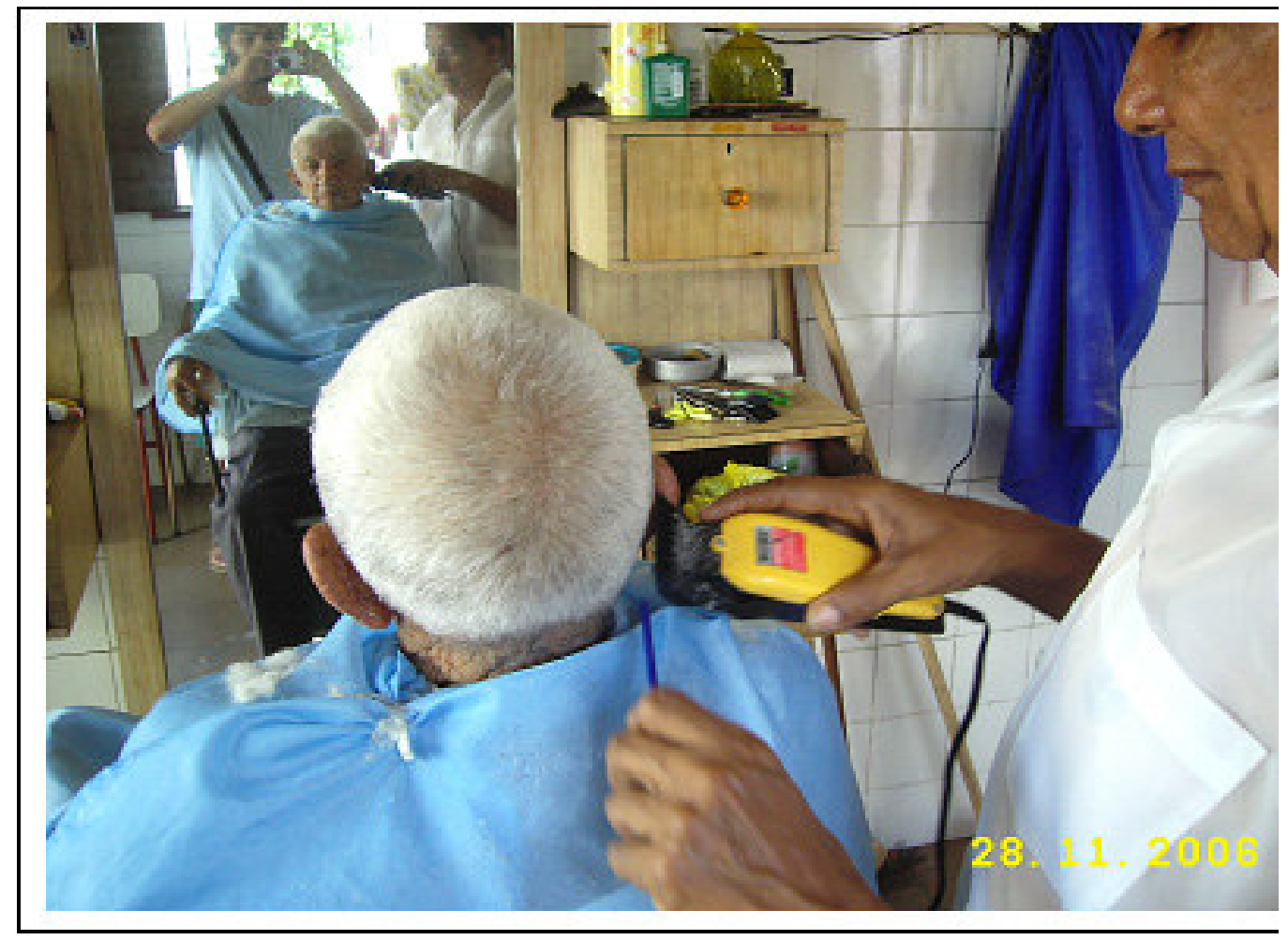

\section{As artes de fazer do barbeiro}

As artes de fazer do barbeiro consistem nas táticas e estratégias usadas em seu ofício de forma a elaborar seguidamente uma artesania singular que busca $o$ aprimoramento de sua performance, utilizando os instrumentos disponíveis na barbearia e técnicas de corte e barbear que satisfaçam o gosto do freguês.

Tais estratégias resultam, em parte, das escolhas - pessoais e aquelas ligadas a melhor qualidade dos serviços - dentre as quais o barbeiro opta em sua arte de cortar e barbear pessoas. Portanto, cabe a ele a decisão de aderir ou não às mudanças proporcionadas pelo avanço das técnicas, bem como ao surgimento de novas ferramentas que auxiliam no ato de cortar cabelos e barbear.

No entanto, percebe-se que uma parte de suas práticas está relacionada à tradição do ofício de barbeiro, na medida em que os instrumentos aos quais dispõem foram, em sua maioria, utilizados pelos barbeiros com os quais aprendeu tal arte e, por certo, pelos barbeiros que ensinaram seus mestres. Ou seja, há o repasse de saberes e fazeres, bem como de ferramentas entre os mais experientes e aqueles que se iniciam nas artes do 
ofício, ligado aos conhecimentos e técnicas aprendidos e acumulados a partir da experiência e da empriria.

Há, dessa forma, uma tensão entre o moderno e o tradicional. Todavia, essa é resolvida pelo barbeiro à medida que desenvolve a sua própria "maneira de fazer". Como disse seu Jorge em uma conversa informal, por mais que o barbeiro seja ensinado de um jeito, ele sempre encontra um melhor, ou seja, um que se adequa melhor ao seu estilo, tornando mais fácil o ato técnico de barbear ou o corte de cabelo.

Estamos, então, diante de uma arte profundamente pessoal, desenvolvida de acordo com os ensinamentos técnicos e o domínio de certas técnicas corporais (Mauss, 1974) oriundos de uma tradição coletiva construída ao longo do tempo. Tais ensinamentos são passados pelo mestre ao aprendiz, adquirindo um estilo pessoal que traz a marca do "artesão" - a do barbeiro - conforme o neófito vai aprendendo a trabalhar sozinho.

Por esta razão, seria desaconselhável falarmos em uma arte de fazer dos barbeiros em geral, posto que nos interessa compreender um saber-fazer que apresenta certas peculiaridades relacionadas ao mundo urbano belemense, ou ainda, aquela ligada à prática de seu Jorge em Icoaraci.

O que fica evidente é que qualquer narrativa sobre o processo de cortar cabelos ou barbear nunca será definitiva, pois se tratando de uma artesania singular - ligada a episódios em que o barbeiro exerce seu ofício em relação a pessoas diversas -, tal prática tende a variar de acordo com a interação junto ao freguês. Toda e qualquer ação técnico-cultural que o barbeiro coloca em prática quando executa seu ofício depende de pelo menos duas dimensões complementares: uma que é de ordem biocultural envolvendo as características capilares e pilosas do freguês (tipo de cabelo e barba; formas de tratamento e higiene dos mesmos) e outra, relacionada à sociação, dada no ato mesmo de cortar e barbear.

Durante uma conversa, seu Jorge mencionou que o barbeiro trabalha de acordo com exigido por seu cliente:

\footnotetext{
“Quais são os passos que o senhor segue quando o senhor corta o cabelo?” (Pedro)

"Os passos, como assim?"

"Os, passos, como o senhor faz... que ordem o senhor segue..." (Pedro)

"Rapaz! (...) A,í o, o cliente pede, né, que faça assim, as vezes, aí, eu, a maior parte já tá acostumado. Eu já sei como é, nem pergunto, né! Aí, vou fazendo aquela maneira que eu fiz a vez passada. As vezes uns modi... querem mudar de corte, mas são poucos que mudam. Ainda mais pessoas idosas, permanecem aquilo mermo, né. Gente quer mais baixa, deixa que é baixinho. Tens uns, aí, que... as vezes corta com a máquina, aí: 'Não, hoje não corta com a máquina, só com a tesoura!"’
} 
Ou então, quando discutíamos as diferenças entre o barbeiro e o cabeleireiro:

\footnotetext{
"E, também tem uma coisa: a diferença, também, que tem é que o barbeiro quase num dá sugestão. Ele repete a sugestão do freguês, né! E, já, se você chegar num salão o cabelereiro:

'Olha, o teu cabelo fica melhor assim, rapaz, num quer fazer luzes? Num quer fazer isso?'

Aí, tem gente que gosta, mas tem gente que num gosta, né. E, na barbearia, não! O barbeiro já recebe sugestão:

'Olha, eu quero meu cabelo assim, assim, dá pra fazer?'

'Bora tentar!'

Eu não gosto de, de, da, né. Quando o cara pede, então... E o pior cabelo que tem pra fazer é aquele, o:

'Olha, do jeito que tu fizer tá bom!'

Não, num é assim, também, né! Não, do jeito que tu quiseres, não do meu jeito! Eu posso achar bacana e, tu pode num achar, num é? Tem isso também, é!"
}

Se, por um lado, é exigida do barbeiro uma decisão quanto ao corte de cabelo a ser efetuado no cliente, sugerindo certo relativismo de sua parte como deixa transparecer no final de sua fala, por outro, o dilema estético colocado ao barbeiro não se extingue, pois existe, por vezes, a necessidade de sugerir ao cliente - ainda que não se sinta à vontade em fazê-lo - o corte mais adequado ao seu tipo de cabelo, formato do rosto, entre outros fatores.

Portanto, o barbeiro deve interagir com o freguês colocando em prática seu senso estético aliado ao conhecimento técnico que detém, de forma a auxiliá-lo a sentirse melhor esteticamente, considerando o estilo de corte que melhor se encaixa às suas características físicas. Seu Jorge fez menção a tal aspecto de seu ofício quando se referiu a um de seus clientes que estaria ficando calvo e, sendo assim, deveria fazer, segundo a sua avaliação, um corte menos rente a cabeça.

Por certo, não há uma maneira generalizada de cortar cabelos entre os barbeiros, aparecendo diferenças, inclusive, entre o barbeiro e o cabeleireiro, pois a maneira de fazê-lo, além de variar de cliente para cliente, tem relação com a forma de cortar que é própria de cada profissional. Além disso, está vinculada, no caso do barbeiro, à relação com o freguês que tende a ultrapassar os limites do corte de cabelo ou do barbear.

Para entendermos melhor certas características que são marcantes no ofício do barbeiro, talvez seja interessante confrontá-lo com a profissão de cabeleireiro, já que as diferenças entre ambos aparecem melhor por contraste. Sendo assim, todas as diferenças elencadas aqui partiram das próprias concepções de seu Jorge, fruto de sua vivência como barbeiro e de sua percepção acerca do outro ofício. De acordo com o senhor: 
"Já, num tem aquele monte de freguês que tinha, como era antigamente, que abriram muitos salões agora modernos, né... Mesmo até inferior do que isso aqui, mas o pessoal dão preferência porque lá... faz unhas, faz penteados, faz pintura e, na barbearia, não! Barbearia, ela é um corte de cabelo simples e a barba, né! Uma coisa mais rápido, como ce vê agora..."

"A diferença é essa..." (Pedro)

"É, do salão, é. No salão, você vai e demora muuito! O cara vai lavar o cabeelo, aqui num tem lavagem de cabeelo, vai botar no secador e tal. Cara também que vai mandar cortar tem que ter um tempo disponível, né. Já, não é o que vem em barbearia, que ele sabe que é rápido: uns cinco minutos, no máximo, vinte... É, né, no salão o cara passa quase até duas horas ou até mais, né, pra aprontar o cabelo. São essas diferenças que tem da barbearia..."

Seu Jorge aponta, então, a barbearia como um lugar onde o corte é mais simples, tratando-se também do local em que se faz a barba, contrastando com o salão de beleza, espaço no qual são oferecidos outros serviços aos clientes, como penteados, lavagem dos cabelos e um corte mais "elaborado". Porém, os profissionais dos salões de beleza geralmente não sabem barbear seus clientes, como afirmou seu Jorge. Há, também, a questão do maior tempo gasto no salão de beleza em relação à barbearia. Quanto às técnicas ou procedimentos utilizados para cortar o cabelo, seu Jorge afirmou:

\footnotetext{
"Eu não corto suspendendo com o dedo, repara que eu meto sempre o pente pra cortar o cabelo em cima do pente. Isso aí é desde quando eu iniciei. Algumas vezes eu pego uma ponta de cabelo e corto. Mas tem camarada que corta o cabelo, cabelereiro, que molha o cabelo, divide em mecha e corta mechado. Isso aí eu não sei fazer, nunca me dediquei nisso, mermo, que quase os meus fregueses não gostum, assim. Aí, fiquei adaptado só nisso mermo, de levantá o cabelo com o pente pra poder cortar".
}

Como veremos mais adiante, o costume de levantar o cabelo com o pente para cortá-lo constitui-se em uma "maneira de fazer" muito importante do ofício de barbeiro. A respeito do público que procura a barbearia, seu Jorge nos fornece pistas de ser a mesma um espaço predominantemente masculino sem, no entanto, excluir necessariamente as mulheres:

\begin{abstract}
"Seu Jorge, barbearia sempre foi uma coisa só de homem mesmo ou o senhor já cortou cabelo de mulher?" (Pedro)

"Já... Cortei! ... Sabe, tinha uma senhora aí, o marido dela muito amigo meu, eu cortava, mandava cortar o cabelo dela igual o do marido. Ele usava o ca... Aí, ele morreu, aí, ela num veio mais aqui. É, num veio mais aqui. Aí: 'Corte o meu igual o do meu marido'. Ele morreu, num sei nem por onde ela mora. Ela... Corta, mas são poucas mulheres, né! Todas que eu cortava cabelo. Mas, já cortei cabelo de mulher aqui. Não tanto quanto de homem, né. Tem barbearias que começaram a botar unissex, né: homem e mulher. A mulher sempre é mais vaidosa que o homem, mas agora já tem homem vaidoso também, né, quer um negócio mais caprichado e tal”.
\end{abstract}

As diferenças entre o barbeiro e o cabelereiro estão explicitadas no quadro seguinte: 


\begin{tabular}{|l|l|}
\hline \multicolumn{1}{|c|}{ Barbeiro } & \multicolumn{1}{|c|}{ Cabeleireiro } \\
\hline Corte simples & Corte mais elaborado \\
\hline Predomínio dos homens & Unissex \\
\hline O Barbeiro segue as "instruções" do cliente & O Cabeleireiro muitas vezes sugere um corte \\
\hline Corte sem lavagem & $\begin{array}{l}\text { Corte com lavagem, além da oferta de outros } \\
\text { serviços (luzes, por exemplo) }\end{array}$ \\
\hline Rapidez no corte (no máximo 20 minutos) & Corte mais demorado (até duas horas) \\
\hline $\begin{array}{l}\text { Corta o cabelo manuseando-o através do } \\
\text { pente. Não toca diretamente o cabelo }\end{array}$ & $\begin{array}{l}\text { Corta o cabelo molhando-o e dividindo-o em } \\
\text { mechas. Segura as mechas entre os dedos. }\end{array}$ \\
\hline Barbeia o cliente se este desejar & $\begin{array}{l}\text { Não sabe ou não gosta de barbear os } \\
\text { clientes }\end{array}$ \\
\hline
\end{tabular}

Considerando que a etnografia em questão baseia-se na apreensão das narrativas de seu Jorge, a fim de compreendermos as suas representações acerca de seu ofício ancoradas nas observações realizadas durante o encontro etnográfico no ambiente de sua barbearia, nada melhor do que descrever a feitura de um corte de cabelo que acompanhamos durante uma das tardes que passamos no estabelecimento em setembro de 2006. Este é um meio de ajudar a entender melhor o savoir-faire de seu Jorge.

O freguês em questão era um homem de aproximadamente 30 anos, sendo o seu cabelo de um tipo crespo, mas fino, com um aspecto ondulado. Tratava-se de um cabelo curto, no estilo militar, o qual foi definido por seu Jorge como "rebaixado".

É importante considerar o cabelo do freguês, uma vez que o barbeiro afirma existir diferenças entre as formas e técnicas utilizadas para cortar um ou outro tipo de cabelo: "Claro que tem, porque são diferentes, né! Aí, tem que ter... diferente. Cabelo liso, geralmente é, as pessoas dizem, é mais ruim de cortar do que o crespo, né!"

No corte feito por seu Jorge no cabelo desse cliente, foi possível identificar pelo menos seis etapas diferentes no processo:

A primeira consistiu no ato de passar a máquina por toda a parte lateral da cabeça, sem tocar na porção superior da mesma. Em seguida, seu Jorge pôs-se a "nivelar" com a tesoura a diferença entre a parte lateral da cabeça - por onde a máquina havia passado - e a parte de cima, onde o cabelo estava maior em relação à lateral. Terminada a segunda etapa, seu Jorge cortou o cabelo da porção superior da cabeça com 
uma tesoura. No quarto ato, o barbeiro passou novamente a máquina sobre a linha divisória entre o cabelo que havia sido cortado com a máquina e o que havia sido cortado com tesoura. Fez isso para garantir que a linha divisória não ficasse evidente, dando ao cabelo o aspecto de uma gradação natural de baixo para cima.

Na quinta etapa, seu Jorge também utilizou um instrumento de "acabamento" chamado "cabelisador", ou seja, trata-se de uma espécie de pente com cerdas curtas dos dois lados, onde estão ocultas pequenas lâminas. Geralmente, depois de terminado o corte, seu Jorge passa tal instrumento pelo cabelo do cliente, fazendo um movimento de frente para trás, como se o estivesse penteando. Desse modo, são tiradas as pontas do cabelo que ficam para cima depois do corte.

Por fim, faz-se o contorno do cabelo com a gilete, buscando acertar a parte de trás do pescoço e a suíça. Está terminado o corte. Seu Jorge retira o "avental” e espana o pescoço do cliente para saírem os últimos "fiapos" de cabelo saídos no corte.

Com relação ao ato de barbear, não há uma forma fixa de proceder, sendo necessária uma abordagem diferenciada de cliente para cliente pelo barbeiro. Assim como no corte de cabelo, a convivência do cliente com o barbeiro ao longo do tempo tende a facilita o barbear, visto que o profissional precisa conhecer o rosto e o tipo de barba do seu cliente. Segundo seu Jorge:

"Aí, você, pra tirar uma barba, você tem que observar se não tem sinal no rosto, quando vai tirar a primeira vez, né. Se num tem sinal, se ela é, ela é certa, porque geralmente as barbas num são... trançadas, né, pra cá, outro cabelo... A pessoa tem que tirar sempre a favor do cabelo. Se meter contra, daí vai estourar a pele da pessoa".

Depreende-se logo que a prática de barbear depende de um amplo leque de conhecimentos empíricos adquiridos ao longo da profissão. Revela-se assim, como um saber não formal, muitas vezes difícil de ser explicado pelo próprio barbeiro, mas pronto para ser posto em prática no momento que for preciso. Portanto, trata-se muito mais de certos fundamentos pautados na técnica e na sensibilidade, utilizados pelo barbeiro para a sua orientação durante o barbear do que um estatuto definido e imutável, como ensina seu Jorge:

\footnotetext{
"Aí, tem, a barba, tem a pele da pessoa fina e a barba grossa, né. Aí, é ruim! Aí, geralmente estoura, sangra e... E é assim, a barba, o cara tem que passar espuma: certas barba, passar o creme, né, de barbear e deixar um pouco o cabelo aparecendo pra ele ver o sentido do cabelo. Entendeu como é? No caso do teu aí - referindo-se à Pedro -, vai pra cá, assim, assim, ó. Aí tem que pegar assim. Se fizer assim, aí, pode estourar, é... É. Vai, faz assim, aí, já vem assim. Mas tem umas que é certinha, que vem todinha aqui, assim. Dum lado, do outro. Que muitas vezes
} 
uma pessoa vê uma barba grande, pensa que é mais ruim de tirar a barba, de fazer. Quando acaba, é melhor que uma pequena, né, que é toda trançadinha. Aí, tem esses detalhes. Aí:

'Não, mas a minha barba é pequena, é o mesmo preço?'

'Não, mas a tua é mais difícil!' (risos).

É igual o careca, né! Que quer pagar a metade.

'Não, mas onde tá a careca é onde não se corta!' (risos).

Né, que é em cima. Tem todo esses detalhes."

A experiência de um dos pesquisadores (Flávio) de ser barbeado por seu Jorge foi interessante para observarmos as técnicas utilizadas pelo senhor, mas também para compreendermos o fenômeno apontado acima pelo barbeiro. Causou estranheza ao senhor a espessura dos pêlos de sua barba e, conseqüentemente, a dureza da mesma em relação aos pêlos de outros homens que o barbeiro está acostumado a barbear em Icoaraci - a maioria deles com poucos pêlos e menos espessos -, deixando-o, até certo ponto, desconfortável para barbear um rosto com uma barba incomum para os padrões masculinos locais.

No processo de barbear, dependendo da necessidade, seu Jorge pode utilizar a chamada "pedra-ume", caso esteja difícil retirar a barba ou corra-se o risco de ferir o rosto do cliente. A utilização da pedra branca e fosca, a qual o senhor passa pelo rosto dos fregueses tem o intuito de "fechar os poros da pele", durante ou após a retirada da barba. Esse expediente visa fazer com que os pelos "apareçam mais" e possam ser retirados mais facilmente pela lâmina do barbeiro e, principalmente, para que seu Jorge termine seu trabalho sem machucar o rosto do cliente. $O$ uso da pedra-ume foi observado uma única vez, quando visitávamos a Barbearia São Jorge.

Da mesma forma, também não foi observado com freqüência o uso do talco por seu Jorge, durante o pós-barba, tendo sido contemplado apenas seu Dori, cliente antigo e amigo de infância de seu Jorge. O que pode explicar a utilização desses dois procedimentos - a pedra-ume e o talco - de forma restrita é, novamente, o caráter individual de corte e barbear requerido no tratamento de cada cliente. No caso de seu Dori, cliente há bastante tempo da barbearia, é mais fácil concluir que a exclusividade no uso do talco relaciona-se a ao conhecimento e à relação de longos anos existente entre ambos. Portanto, seu Jorge já sabe o que fazer.

No tocante à pedra, seu Jorge não soube explicar o critério de sua utilização, embora se saiba que ela seja necessária em casos nos quais o cliente possui uma barba muito espessa. Isso não significa que seu Jorge não saiba ou não possua um critério para utilizar a pedra. Muito pelo contrário, ele tem domínio da técnica, no entanto, tal saber manifesta-se justamente quando é requerido. Ou seja, de acordo com a ocasião, revela- 
se o momento exato para realizar o trabalho da memória (Bosi, 1994) e colocar em prática enquanto uma estratégia (Certeau, 1998), o gesto técnico (Leroi-Gourhan, 1990) que implica o domínio de uma ferramenta.

O que parece evidente é que a arte do barbeiro é uma arte do detalhe: “Tem todo esses detalhes!" É uma arte que envolve a observação minuciosa, porque é preciso atenção aos conjuntos face/cabeça; cabelo/barba: identificando sinais e marcas corporais do sujeito que está em sua frente. Implica, além disso, em certa dose de improviso, já que nem todas barbas são iguais. A arte do barbeiro, portanto, estetiza o outro, uma vez que arranja formas definindo novas, no próprio ato de (re)compor uma imagem pessoal. Trata-se de uma arte que prioriza o belo, ou ainda, toma uma idéia (inter)subjetiva dada na relação do si com o outro - do que seria belo, como o resultado de seu ofício.

Numa conversa com o senhor resolvemos explorar mais alguns detalhes do conhecimento empírico adquirido nos anos de profissão. Seu Jorge prosseguiu:

\begin{abstract}
“Tem barba que é mermo, é até dolorida da... tem pessoa que tem barba dolorida assim, pra tirar. Tem que tirar com bastante calma, aí. Outras não, o cara pode meter a lâmina e puxar, né. Uma que são dolorida, a pessoa... E também tem o poblema das lâminas, né, gilete, que agora não é mais navalha, é gilete!... As lâmina tem que ser lâmina boa. Tem pessoas que também, uma, uma gilete muito amolada, muito fina é ruim de tirar também, tem que ser a gilete mais grossinha, pra poder tirar. Tem algumas qualidade de gilete, aí, que... agora num... Aquela Platinum Plus, pra mim era a melhor. Num existe mais. Tem Platinum, mas num é Platinum Plus. É outro tipo de Platinum. Ah, eu uso mais a Wilkson, agora, A4. Ela é boa. Essa que eu fiz a tua barba foi A4, foi $\mathrm{A} 4{ }^{10}$,
\end{abstract}

Outra questão fundamental no ofício do barbeiro está relacionada ao improviso, pois sugere a necessária criação de estratégias para lidar com situações que se apresentam em sua tarefa. Seu Jorge, por exemplo, colocou o problema da compatibilidade entre a qualidade da gilete (o instrumento de trabalho) e o tipo de barba do cliente (a matéria de sua labuta). Ou seja, é preciso improvisar no uso das ferramentas de trabalho, pois, além disso, várias delas caíram em desuso com o passar do tempo, como é o caso da navalha. Hoje em dia seu Jorge usa o navalhete instrumento semelhante à navalha -, com a diferença de ser possível trocar as giletes após o uso. No entanto, mesmo alguns tipos de gilete, como é o caso da Platinum Plus, citada por seu Jorge, já não existem mais.

Cabe, então, ao barbeiro possuir certa versatilidade para adaptar-se às mudanças provocadas pela passagem do tempo associada às modernizações, sem abrir mão do

\footnotetext{
${ }^{10}$ Referindo-se a barba de Pedro.
} 
caráter tradicional que é próprio de sua profissão. A respeito das modificações sofridas pelo ofício ao longo do tempo, o senhor nos contou:

\begin{abstract}
“Ah, mudou muita coisa, né. Pelo menos a máquina não era elétrica, era manual, né. As tesouras eram tesouras de aço que a gente colocava, uma pegava na outra... Navalhas, navalhas tinha que ter o afiador pra afiar ${ }^{11}$. Mudou muito. Esses vaporizadores, aí, de plástico, eram tudo, eram todos de... era tipo um metal, antimônio. Era... uma borracha pra dar pressão pra água sair. Tinha de pó também. As escovas eram diferentes. É, mudou muito, né. Com o tempo tudo muda, vai mudando assim... Mudou muito mermo, é. O tipo de cadeira, essa minha cadeira ela tem uns trinta e nove anos, uns trinta e nove anos mais ou menos. Mas eu já remodelei... Agora, são umas cadeiras, me parece que até mais frágeis... Mudando, foi mudando, foi mudando, foi mudando... É. Quando começou era com aquelas máquina manual, e era diferente o corte, né. Agora não, [foi] mudando, porque tudo muda, né! Aí, vai passando, vai mudando..."
\end{abstract}

Em relação aos estilos dos cortes de cabelo de outrora, aos quais seu Jorge se referiu em sua fala, foram enumerados alguns deles, como o "estaqueado", o "rebaixado", o "busca-ré" e o "cheio". Conforme nos disse o senhor:

"Mas sempre teve também, né, os corte antigo. Antes de aparecer as máquina elétrica, os cara usavo aqueles cabelo, era... tinha um que chamava 'busca-ré'. Era 'busca-ré'! 'Busca-ré' era bem baixinho assim, em cima, né. É quase como usam agora. Só que era feito com tesoura e pente: a máquina num tinha, né. É, com a tesoura e pente o cara fazia, aquilo dava um trabaalho... Aí, hoje em dia não, pra fazer 'busca-ré', o cara, é um quadrado aqui em cima sabe, assim. Em vez de ficar boleado em cima, aí, fica assim. Era, me lembro, 'busca-ré'. Era 'rebaixado', 'aparado', 'cheio'. 'Cheio', assim, era mais cabelo do que tá o teu assim (risos), é 'cheio', assim, fazia a voltazinha, assim... 'Rebaixado', geralmente, era quase um meio militar assim, e, bem baixinho aqui, 'rebaixado'. Rebaixava bem e ficava mais cheio um pouco... Como eu fiz com esse rapaz assim é ‘estaqueado', né. Desse aí! Mas só que levou a máquina pelo lado, antigamente o 'estaqueado' era só com a tesoura mermo..."

“Como é que era o 'estaqueado'?” (Pedro)

"'Estaqueado', é, ficava igual no lado, igual em cima, tudinho assim por igual, por igual. Aí, o dele ainda ficou um pouco mais alto em cima".

A respeito dos cortes mais contemporâneos, seu Jorge ao estabelecer relações com os "antigos", afirmou: "Era esses corte! Agora, não se usa mais isso, o cara chega: 'Olha, faz assim!' Quem dá as ordem é o cliente: 'Eu quero meu cabelo assim, assim, assim, ó! Corta assim! Vai cortando aí, é!' Vão dizendo, a pessoa vai fazendo”.

Seu Jorge retoma em sua narrativa uma das características do ofício do barbeiro, ou seja, a de seguir sempre as orientações dos clientes em vez de tentar dar sugestões. Em outra passagem de uma conversa com seu Jorge, ele complementou tal questão, no sentido de evidenciar os estilos de cortes realizados hoje em dia:

\footnotetext{
${ }^{11}$ Seu Jorge costumava ir todas as segundas-feiras à rua Frei Gil, no bairro Cidade Velha a fim de amolar seus instrumentos - tesouras, máquinas e navalhas.
} 
“Agora, tem as máquina, né! Máquina elétricas que cortam e fica legal. [A] Maior parte, agora, em barbearia, aí, o cara: 'Olha, põem a 2, põem a 3, põem a 4, chega a 5 a , é máquina..."

"Mais máquina, né?" (Pedro)

"É. Usam mais máquina. Por isso que eu tenho muita máquina [...] Aí, quando esquenta uma eu passo pra outra. E assim vai!"

A sua fala reafirma outra característica das barbearias, posto que nelas, segundo a perspectiva de seu Jorge, são feitos cortes mais simples, ou ainda, necessitam de menos elaboração, utilizando-se, muitas vezes, apenas as máquinas-elétricas. No entanto, assim como o barbear, a prática de cortar cabelo também necessita do domínio de um conjunto de técnicas e de conhecimentos empíricos a ela relacionados:

\footnotetext{
"E a máquina sempre ela, ela é um corte assim mais certinho, né. E a tesoura já é mais técnica mesmo, mais conhecimento, que o cara tem que fazer o cálculo ali, na... o pente com a tesoura, pra não ficar tão diferente um lado do outro, né. Apesar de nós não termos um lado certo, um lado, geralmente, é dum jeito, o outro é do outro, né! O cara, né, se aproxima. No caso teu aqui, ó, daqui já é mais tufado um pouco, né!"

"É?" (Pedro)

"É...(risos). Cara olha, assim, tem que olhar..."
}

Mais tarde, em conversas informais, seu Jorge falou que a pessoa destra tem mais cabelo do lado direito, e quem é canhoto possui mais cabelo do lado esquerdo. Ele aprendeu isso quando fazia um curso com um cabeleireiro, há algum tempo atrás. Também mencionou que, geralmente, o lado esquerdo da cabeça é mais baixo que o lado direito. Com a barba, muitas vezes, aconteceria a mesma coisa, posto que ao não ser simétrico o rosto do cliente, a barba tenderia a se distribuir diferentemente nos dois lados da face.

As colocações de seu Jorge acerca das diferenças entre o lado esquerdo e o direito da cabeça remetem ao estudo clássico de Robert Hertz - "A preeminência da mão direita: um estudo sobre a polaridade religiosa", de 1909 -, onde o autor analisa a polaridade sagrado/profano presente nas figuras do destro e do canhoto, refletindo-se numa simbólica ligada à ordem do universo. Na perspectiva do barbeiro tal polaridade traduz-se na maior ou menor quantidade de cabelos na cabeça/pêlos da barba do cliente. Aqui, de alguma forma, retornamos à dimensão sensível da mão associada à polaridade direita/esquerda existente no corpo, no caso, na cabeça. De acordo com Hertz:

\footnotetext{
"Uma concordância não menos significativa liga os lados do corpo a regiões no espaço. A direita representa o que é alto, o mundo de cima, o céu; enquanto que a esquerda está associada ao mundo subterrâneo e a terra (...) $\mathrm{O}$ eixo que divide o mundo em duas metades, uma radiante e outra escura, atravessa também o corpo humano e o divide entre o império da luz e o da
} 
escuridão. Direito e esquerdo se estendem além dos limites do nosso corpo e abarcam o universo". (Hertz, 1980:112-13)

É, então, trabalho do barbeiro buscar esta simetria, ou ainda, modelar através do corte ou do barbear, o que percebe como desigual. O barbeiro delineia formas tanto em relação ao cabelo quanto à barba: repara inexatidões; conserta assimetrias; disfarça o que destoa; retraça linhas formais da face, enfim, estetiza o outro numa busca artesanal pelo que seria um modelo harmônico e agradável ao olhar.

O barbeiro lida com uma matéria singular como é o tecido capilar, cuja simbólica está associada à noção de corpo em consonância com uma idéia de moda que variam ao longo do tempo, ligando a percepção de si ao jogo intersubjetivo dado na visão do Outro acerca de mim e vice-versa. Ele, portanto, embeleza o outro que está numa busca de satisfação pessoal, mas que vislumbra a aceitação por parte das demais pessoas em relação aos usos que faz de seu corpo.

Em seu ofício, o barbeiro busca certa perfeição no resultado final. Trata-se de um artesão que, ao invés de lidar com a plasticidade de uma matéria outra (barro, metal, pedra, entre outras), encontra nos pêlos a possibilidade de moldar as formas que valorizam o rosto como um elemento expressivo da experiência social do sujeito no mundo. $\mathrm{O}$ barbeiro procura encontrar a simetria em seu trabalho modelando o cabelo da mesma forma que o oleiro modela uma peça de cerâmica ${ }^{12}$.

Seu Jorge não toca o cabelo com as mãos, somente através de seus instrumentos específicos de trabalho: o pente e a tesoura. Por intermédio dessa técnica, ele vai construindo a sua obra, confiando naquilo que vê, numa artesania sensível que elabora as formas num processo criativo de estetização do Outro.

Daí, que em sua tarefa, caso perceba que o corte não está igual nos dois lados da cabeça, retoma o mesmo e corta onde considera que deve fazê-lo - ou seja, estabelece um juízo estético - e, assim, procede até findar o trabalho. Além disso, o barbeiro precisa fazer o acabamento do corte, isto é, livrar-se dos cabelos que restaram em certo desalinho - despontando acima do conjunto - da mesma forma que o artesão lixa a peça de barro recém saída da cerâmica.

\footnotetext{
${ }^{12}$ Gilbert Durand (1995:17) ao considerar uma "linhagem dos sapateiros", reflete sobre uma simbólica presente na "arte do sapateiro", entende que "de certo modo seu savoir-faire" permite que o "celeste se revele na criação, na criatura, na natureza. A Imaginatio vera é a agulha e a linha que unem a intenção divina à natureza, isto é, a alma humana". Neste caso, tanto o barbeiro quanto o oleiro, ao buscarem certa ordem nas formas se aproximariam da imagem mística do sapateiro , uma vez que, como ele, estariam "do lado dos sentidos e dos sentimentos do homem".
} 
O resultado final é uma obra de arte onde a subjetividade do barbeiro ressoa na imagem não menos subjetivada do Outro. Devaneio que alia técnica e imaginação na ação das mãos sobre a matéria - o cabelo do cliente -, transformando-a em algo diferente, imprimindo nela uma forma ligada ao gênio humano de estetizar o mundo.

\section{A barbearia como espaço de interação social: labuta e sociabilidade}

A relação barbeiro/cliente é um aspecto fundamental para compreendermos a barbearia como um espaço no qual a vida vivida, engendra formas singulares de interação social no mundo urbano contemporâneo belemense. Tal fenômeno instiga-nos a pensar acerca das razões que fazem pessoas vir de locais considerados distantes - "lá da Berredos ${ }^{13}$ " -, ou chegando à barbearia de automóvel para requisitar os serviços de seu Jorge, o que sugere certa distância da casa até o estabelecimento do senhor. Em uma de nossas primeiras visitas à barbearia, conversamos com o barbeiro sobre o assunto:

\footnotetext{
“Todo barbeiro tem uma clientela fixa?" (Pedro)

"É, é, gostava de cortar..."

"O pessoal de outro bairro vinha cortar com o senhor?" (Pedro)

"Vinha, vinha... É, vinha cortar. Sempre tem, né! O cara tem aquela preferência, tem aquela amizade, aquele conhecimento, né. Já vem, passa por diversas barbearia e vem cortar. Porque nem todo mundo aqui perto corta cabelo comigo, entendeu? É, tem outros que cortum lá adiante, outros já vão pro salão... Tem que ter os outros de longe, também.”
}

A lógica do relacionamento cliente/barbeiro parece ser um dos traços reveladores do tradicional nessa profissão, pois se baseia em uma relação de cunho pessoal construída entre os dois ao longo do tempo, como fica claro pela presença de seu Grimualdo Soares (55 anos) na barbearia São Jorge, freqüentando a mesma desde os 12 anos de idade.

O que chama a atenção é o fato de que, a despeito do tempo que seu Grimualdo é cliente de seu Jorge, 43 anos, o senhor não mora nas redondezas da barbearia, e sim "lá pra Berredos". Ao ser questionado acerca do que fazia um cliente como seu Grimualdo, que não mora perto do estabelecimento, voltar regularmente à barbearia desde criança, seu Jorge respondeu: "Essa amizade que o cliente já chega aqui e eu não pergunto nem como é o corte!’.

\footnotetext{
${ }^{13}$ Rua relativamente distante da barbearia São Jorge, estando mais próxima ao bairro do Paracuri do que da Orla do Cruzeiro. Sua referência, geralmente, vem acompanhada de locuções adverbiais que denotam um certo distanciamento em relação aos bairros centrais de Icoaraci: "Lá na Berredos", ou "Lá pra banda da Berredos".
} 
O termo amizade ${ }^{14}$ ao aparecer no discurso de seu Jorge, revela uma questão importante para o entendimento das formas de relacionamento existentes entre seu Jorge e sua clientela. Para termos uma idéia mais clara do que significa tal categoria, ou seja, no que constituía essa "amizade", perguntamos a alguns dos clientes de seu Jorge que se mostravam mais abertos porque persistiam em retornar à barbearia durante tanto tempo.

Seu Dori, por exemplo, cliente há vinte e cinco anos, vai à barbearia todo mês. Disse a respeito de seu Jorge: "Bom barbeiro, trata respeitosamente, é um amigo! Corta muito bem o cabelo". Quando seu Dori deixou a barbearia, depois de conversar um pouco com seu Jorge, este me disse conhecer seu Dori desde criança.

Em outra visita a barbearia, conhecemos seu Salomão, o cliente mais idoso de seu Jorge, hoje com noventa e quatro anos de idade. Quando questionado sobre sua experiência na barbearia de seu Jorge, ele disse que a freqüentava há quinze anos, ou seja, desde os setenta e nove anos de idade. Afirmou: "Quando a gente acha um barbeiro que trata a gente bem, aí, não tem outra coisa!’ Seu Salomão também falou que seu Jorge dava uma gratificação no fim do ano. Ao ser indagado sobre tal gratificação, respondeu que a gratificação de seu Jorge é receber muito bem, tratar bem os fregueses.

Percebe-se logo que o relacionamento de seu Jorge com seus clientes é um fator fundamental para fazê-los retornar à barbearia, uma vez que o "tratar bem" e a "amizade" parecem ser tão importantes quanto a destreza de seu Jorge como barbeiro. Não se trata de uma relação puramente comercial, onde haveria apenas uma simples troca de valores materiais estabelecida pela relação corte de cabelo/pagamento. Há algo mais envolvido nessa interação, pois ela não se esgota no plano meramente econômico. No entanto, tampouco o barbeiro e o cliente ultrapassam certos limites subjetivos que os levem a invadir a vida privada um do outro.

Certeau (1994) ao analisar o relacionamento entre cliente e comerciante, demonstra a existência de elementos ligados à confiança, assiduidade e exclusividade. Sendo assim, temos, para o caso do barbeiro e seu freguês, formas de relação similares. Um fator decisivo para manter a continuidade deste laço é a amabilidade entre ambos. Esta, porém, seria praticada dentro de determinados limites estabelecidos por eles. Tais limites são ditados pelo que Certeau chama de "conveniências", ou seja, o caminho trilhado e as decisões tomadas pelos indivíduos de maneira a possuírem boas relações no bairro em que vivem.

\footnotetext{
${ }^{14}$ Acerca da importância da amizade no trabalho de campo e suas implicações para uma Antropologia das Emoções, ver as reflexões de Rabinow (1988).
} 
Desse modo, as artes de fazer do barbeiro não compreendem apenas as técnicas, os gestos e as maneiras de fazer ligadas ao seu ofício e responsáveis pelo aprimoramento de sua performance, ou mesmo, às formas de conhecimento empírico adquiridas ao longo dos anos. As artes de fazer do barbeiro se estenderiam também a uma maneira de tratar, de falar e se portar diante dos freqüentadores de sua barbearia.

Sendo assim, os homens que freqüentam a barbearia tornam-se clientes e retornam não somente pelo corte de cabelo ou para fazer a barba, mas para retribuir o bom tratamento que lhes é dispensado. Estabelece-se uma relação de dom e contra-dom entre o barbeiro e o freguês (Mauss, 1974), sendo este um fator decisivo para a aquisição e perpetuação do hábito de freqüentar a barbearia, tanto quanto a virtuosidade do barbeiro em sua profissão.

Por esta razão, o relacionamento entre os clientes e seu Jorge pode estar inserido em uma perspectiva de sociabilidade no contexto icoaraciense. As relações construídas na barbearia, no entanto, não tendem, normalmente, a chegar a um nível muito elevado de intimidade pessoal.

Para Simmel (1983) essa seria uma característica da sociabilidade, pois de acordo com o autor, o único objetivo da sociabilidade é o próprio sucesso do momento sociável. A conversa sociável é uma interação na qual nenhum dos participantes apresenta aspirações concretas, ou objetivos específicos que tenderiam a extrapolar o momento vivido. Da mesma forma, os indivíduos também não exacerbam demasiadamente a sua subjetividade, pois isso iria contra as conveniências e obscureceria o que realmente conta para o alcance do sucesso do momento sociável: a troca de valores sociais, ou seja, a amabilidade, o bom-humor, o "tratar bem".

As conversas na barbearia refletem muito bem este clima de descontração desinteressada e contida, na medida em que a política, o futebol e as recordações sobre o passado, constituem assuntos que não se estendem longamente e cumprem função de entretenimento amigável. É a conversa pela conversa, não se chegando a conclusões definitivas e nem se impondo pontos de vista.

A barbearia é um espaço de sociabilidade no qual, predominantemente, homens mais velhos vão para cortar o cabelo e fazer a barba, mas também para ler o jornal, desfrutar de uma boa conversa e, é claro, retribuir o bom tratamento dispensado por seu Jorge. Portanto, as artes de fazer do barbeiro estão estreitamente ligadas à sociabilidade no bairro, pois o corte, o barbear e sua forma de tratar os clientes mantêm a assiduidade dos fregueses ao longo dos anos. 
Nestes termos, a barbearia São Jorge seria um exemplo de como determinados espaços vinculados a profissões tradicionais perduram no contexto icoaraciense, como uma nuance da permanência de estilos de vida que remetem à dinâmica do tempo entre as populações amazônicas, constantemente confrontadas com a modernização da prestação de serviços no distrito.

O estabelecimento é uma referência importante na vida cotidiana de muitos homens, seja do bairro ou de longe dele, uma vez que muitos ex-moradores das redondezas continuam voltando à barbearia, mesmo depois de terem se mudado do local para pontos mais afastados do distrito. Além do mais, os antigos freqüentadores ajudam a perpetuar a tradição de procurar o barbeiro, levando seus filhos e netos à barbearia. É comum seu Jorge perguntar: "Como está teu pai?”, ou, afirmar: "Eu cortava o cabelo do teu avô!".

Seu Jorge recorda-se de tempos passados, nos quais a barbearia estava sempre cheia, quando certos personagens animavam o local com histórias de "visagens" e anedotas. Conta ele que aos sábados vinham pessoas do Tenoné ${ }^{15}$, pois lá não havia lugar para cortar cabelo. Diversas vezes seu Jorge chegara às 22 horas trabalhando, hábito que pode ter provocado seqüelas em sua saúde em virtude das longas horas nas quais esteve em pé - como o surgimento de varizes - a trabalhar. Sobre o ofício de barbeiro nos dias de hoje, seu Jorge comentou:

“É, barbeiro vai acabando! Hoje em dia quase já num tem mais barbeiro, né! Agora, tem mais é salão, é aquele negócio, aí, o cara quer tirar uma barba, aí, já num sabe tirar ou não gosta de tirar... Barbeiro... de primeiro a gente se conhecia tudo! Agora, não! Tem ainda ali o filho do Peri, né... Eu sei os filho do Peri... É, tem o Raimundinho na, é, Raimundinho ali na $6^{\mathrm{a}}$ rua, também, eu num sei se ele ainda trabalha, o Raimundinho... Aí os outros eu num sei bem, tem ali, na Campina, mas eu num conheço... Agora, tem os outros salão pra cá pra banda, mas acho que aquilo não é barbearia! Esses novos são diferentes e é gente mais jovem, né... Eu sei esses aí. Mas tinham muitos barbeiros em Icoaraci, de primeiro. Icoaraci era muito, barbearia. Em, em frente a mercado ali tinha uma barbearia, trabalhavam bem uns cinco, todos já morreram (risos). Como é a vida, né? O cara vai, vai e morre..."

Seu Jorge, ao mergulhar no passado, traz à tona a sua visão acerca das transformações experienciadas por ele na vida cotidiana do bairro, as quais são reveladas mediante o fato de que as pessoas não se conhecem mais como outrora, revelando que os laços de sociabilidade se fragmentam com o passar do tempo.

Tal fenômeno está associado ao escasseamento das barbearias no distrito e a substituição paulatina dos salões de beleza - colocando novas percepções estéticas no

\footnotetext{
${ }^{15}$ Bairro de Belém próximo à Icoaraci.
} 
mundo urbano de Icoaraci - em relação às antigas barbearias. Os barbeiros, na visão do senhor diminuem não apenas pela concorrência com os salões, mas também, por que morrem. É da finitude do ser que seu Jorge trata e, conseqüentemente, de uma memória ligada às artes de fazer do barbeiro que se dissipa parcialmente com o desaparecimento de tais figuras do cenário urbano icoaraciense.

No entanto, seria simplista afirmar que o ofício de barbeiro está destinado a acabar, pois a relação barbeiro/freguês transforma-se com a chegada dos salões, ao mesmo tempo em que alguns de seus clientes falecem, uma vez que a clientela tende a se renovar, pois os filhos e netos de seus antigos clientes adquirem o costume de freqüentar a barbearia.

O que parece mais evidente, neste caso, é fato de que a permanência do ofício de barbeiro depende muito mais de existirem novos aprendizes - fato do qual seu Jorge se ressente - do que da diminuição da procura pelos serviços do barbeiro pela clientela. $\mathrm{Na}$ verdade, o que parece ser o grande trunfo de seu Jorge como barbeiro reside nele romper com a lógica impessoal e massificada da prestação de serviços própria da sociedade moderna.

\section{REFERÊNCIAS}

BACHELARD, G. A Poética do Espaço. São Paulo: Martins Fontes, 1988.

BACHELARD, G. A Terra e os Devaneios da Vontade: ensaio sobre a imaginação das forças. São Paulo: Martins Fontes, 1991.

BACHELARD, G. A Terra e os Devaneios do Repouso: ensaios sobre as imagens da intimidade. São Paulo: Martins Fontes, 1990.

BENJAMIN, W. O Narrador. São Paulo: Abril Cultural, 1980.

BOSI, E. Memória e Sociedade. Lembranças de Velhos. São Paulo, Companhia das Letras, 1994.

DE CERTEAU, M; GIARD, L; MAYOL, P. A Invenção do Cotidiano Vol. 2. Morar, cozinhar. Petrópolis: Vozes, 1994.

DURAND, G. A fé do sapateiro. Brasília: UnB, 1995.

FOCILLON, H. A vida das formas. Seguido de Elogio da Mão. Lisboa: Edições 70, 2001.

FOOTE-WHYTE, W. Treinando a observação participante. In: ZALUAR, A. (org.), Rio de Janeiro: Francisco Alves, 1980, p.77-86.

GALVÃO. E. Santos e visagens. Um estudo da vida religiosa de Ita, Baixo Amazonas. São Paulo: Ed. Nacional; Brasília: INL, 1976

HALBWACHS, M. A memória coletiva. São Paulo: Vértice, 1990.

HERTZ, R. A preeminência da mão direita: um estudo sobre a polaridade religiosa. Religião e Sociedade. n6, 1980, pp.99-128.

HUIZINGA, J. Homo ludens. São Paulo: Perspectiva, 1990.

LEROI-GOURHAN, A. O Gesto e a Palavra - Técnica e Linguagem. Lisboa: Perspectiva do Homem/Edições 70, 1990. 
LEROI-GOURHAN, A. O Gesto e a Palavra - Memória e ritmos. Lisboa: Perspectiva do Homem/Edições 70, 1987.

LÉVI-STRAUSS, C. A oleira ciumenta. São Paulo: Brasiliense, 1986.

MAUSS, M. "Ensaio sobre a dádiva. Forma e razão da troca nas sociedades arcaicas". In: In: Sociologia e Antropologia. V II, São Paulo: EPU, 1974.

MAUSS, M. "Técnicas Corporais". In: Sociologia e Antropologia. V II, São Paulo: EPU, 1974.

RABINOW, P. Un Ethnologue au Maroc. Refléxions sur une enquête de terrain. Paris: Hachette, 1988.

SANSOT, Pierre. Pour une esthétique des paysages ordinaires. Ethnologie Française, CNRS/Réunion des Musées nationaux. V.19. n³, 1989, ps. 239-243.

SANSOT, Pierre. Variations paysagères. Paris: Klincksieck, 1983.

SCHAMA, Simon. Paisagem e Memória. São Paulo: Companhia das Letras, 1996.

SIMMEL, G. Sociologia. In: FILHO, E. de M. (org). São Paulo: Ática, 1983.

WAGLEY, Charles. Uma comunidade amazônica: estudo do homem nos trópicos. Belo Horizonte: Itatiaia; São Paulo: Edusp, $3^{\text {a }}$ ed., 1988. 